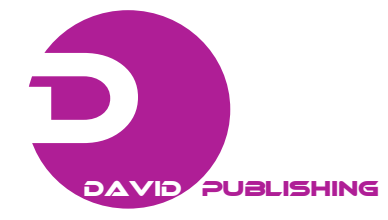

\title{
Effect of Modified Atmosphere Packaging on Postharvest Quality of Barangan Banana
}

\author{
Elisa Julianti, Ridwansyah and Era Yusraini \\ Department of Food Science and Technology, Faculty of Agriculture, University of Sumatera Utara, Medan 20155, Indonesia
}

Received: October 13, 2011 / Published: January 20, 2012.

\begin{abstract}
An experiment retail film packaging system was used to compare the atmospheric composition within sealed packs containing barangan banana fruits. This research was done in order to study the effect of packaging films with different permeability properties on the physicochemicalproperties of barangan banana during storage at room temperature $\left(28 \pm 2{ }^{\circ} \mathrm{C}\right)$ and at $15^{\circ} \mathrm{C}$. The films used were $0.09 \mathrm{~mm}$ low density polyethylene (LDPE), $0.04 \mathrm{~mm}$ polypropylene and $0.057 \mathrm{~mm}$ LDPE compared with unwrapped fruits as control. Barangan bananas were evaluated each 5 days intervals for changes in moisture content, total sugars, vitamin $\mathrm{C}$, hardness and color. Unwrapped barangan bananas were overripe and soft after 15 days at both temperature conditions. Sealed packages especially using LDPE at $15{ }^{\circ} \mathrm{C}$ delayed the development of the yellow color of banana until 20 days of storage and had the lowest weight loss.
\end{abstract}

Key words: Modified atmosphere packaging, barangan banana, film plastic, postharvest.

\section{Introduction}

Barangan banana (Musa AA Group) is one of the commercial banana cultivars grown in North Sumatera, Indonesia. It is an important commodity for export, and today shares the highest export value among commercial banana cultivars in Indonesia especially in North Sumatera [1]. They are chiefly eaten raw as a dessert fruit, because in the ripe stage they are sweet and easily digestible [2].

Due to its perishable property, unproper post harvest handling and the hot and humid weather in Indonesia, the produce deteriorates very rapidly and therefore the post harvest losses is still high. This results in difficulties in providing the good quality products for consumers in domestic and export [3].

There is a need to find appropriate storage method to extend the storage life to maintain the fruit quality for long distance transportation for domestic and export

Corresponding author: Elisa Julianti, lecturer, researcher, research field: postharvest rechnology. E-mail: elizayulianti@yahoo.com, elisa1@usu.ac.id. markets. Modified atmosphere packaging (MAP) is an ideal preservation technique and is known to have great potential to extend the shelf life of fruits and vegetables [4]. MAP has proven to be a successfull means of reducing the post harvest losses and can prolong the post harvest life of various banana cultivars [2-5]. The research was carried out to test the effect of packaging films with different permeability properties on the physiochemicalproperties of barangan banana during storage at room temperature $\left(28 \pm 2{ }^{\circ} \mathrm{C}\right)$ and at $15^{\circ} \mathrm{C}$.

\section{Materials and Methods}

Bananas (Barangan) used in this study were purchased from a farmer in Talun Kenas Village, North Sumatera province. Bananas were harvested at $80 \%$ maturity. They are trasported by car to the laboratory within 3 hours after harvest. They were separated from their hands and selected to uniformity of size, color and weight. No postharvest chemicals or fungicides were applied. Three to four fingers of bananas were randomly placed in individual tray foam and wrapped 
by non-perforated $0.09 \mathrm{~mm}$ low density polyethylene (LDPE) or $0.04 \mathrm{~mm}$ Polyprophylene (PP) or $0.057 \mathrm{~mm}$ LDPE, and unwrappped fruits as control. The permeability of plastic films at $25^{\circ} \mathrm{C}$ to $\mathrm{CO}_{2}$ and $\mathrm{O}_{2}$ were 1,002 and $3,600,229$ and $656,4,143$ and 6,226 mL.mil.m $\mathrm{m}^{-2} \mathrm{hr}^{-1} \mathrm{~atm}^{-1}$ for $0.09 \mathrm{~mm}$ LDPE, $0.04 \mathrm{~mm}$ PP and $0.057 \mathrm{~mm}$ LDPE respectively. All bananas were stored at room temperature $\left(28 \pm 2{ }^{\circ} \mathrm{C}\right)$ or $15 \pm 1^{\circ} \mathrm{C}$, for 20 days. Banana quality evaluations were performed after storageand included weight loss, moisture content, vitamin $\mathrm{C}$, total sugar, soluble solids concentration (SSC) and fruit firmness. Visual appearance evaluated included color, aroma, texture and overall appearance.

\subsection{Weight Loss}

Weight loss was calculated using a balance with an accuracy of $0.01 \mathrm{~g}$ (Sartorius) and expressed in percentage of fresh weight.

\subsection{Vitamin C Content}

Vitamin C content was determined in fruit juice by using the dye 2,6-dichlorophenyl indophenols method described in Ref. [6]. The results were calculated as mg per $100 \mathrm{~g}$ fresh weight.

\subsection{Total Sugar}

Total sugar were determined by using anthrone method described by Southgate [7]. Results were expressed as percentage of fresh weight.

\subsection{SSC}

SSC were determined as ${ }^{0}$ brix by placing a drop of juice on the prism of hand refractometric (RHB-32 ATC) at $25^{\circ} \mathrm{C}[6]$.

\subsection{Fruit Firmness}

Fruit firmness was determined by using a texturometer instrument and the results were expressed as $\mathrm{g}$.

\subsection{Visual Appearance}

Visual appearance evaluated included color, aroma, texture and overall appearance using 5-point hedonic scale and was conducted by 15 semi-experienced panelists.

\subsection{Changes in Gas Composition within Packages}

The concentration of carbon dioxide and oxygen within the packed units were measured by using cosmotector type XPO 318 for oxygen and XP 314 for carbon dioxide.

\subsection{Statistical Abalysis Procedure}

All data parameters studied were analyzed as Factorial Completely Randomized Design in factorial arrangement with three replications. Data were statistically analyzed by the analysis of variance (ANOVA), and means were compared by the Tukey Test at a significance level of 0.05 using Minitab 14 software.

\section{Results and Discussion}

\subsection{Changes in Gas composition within Packages}

A decrease in $\mathrm{O}_{2}$ (about $2 \%$ to $7 \%$ ) and an increase in $\mathrm{CO}_{2}$ (more than $10 \%$ ) within the packages were reached in 18 hours storage in room and $15{ }^{\circ} \mathrm{C}$ of temperature (Fig. 1). $0.09 \mathrm{~mm}$ LDPE films had comparatively lower concentration of $\mathrm{CO}_{2}$ in MAP than $0.057 \mathrm{~mm}$ LDPE and $0.04 \mathrm{~mm}$ PP both in low and ambient storage. Similar pattern of changes in gaseous atmosphere were reported $[5,8]$. The steady levels of $\mathrm{CO}_{2}$ and $\mathrm{O}_{2}$ in these packages could cause marked changes in the activities of specific enzymes in the respiratory metabolism and might have uncoupling effect on oxidative phosphorylation [9]. This might have led to the extension of shelf life of barangan banana in MAP at room and $15{ }^{\circ} \mathrm{C}$ of temperature more than 15 days and 20 days respectively as compared to 15 days in unwrapped control.

\subsection{Weight Loss}

Weight loss of barangan banana increased during ambient and cold storage (Fig. 2). However, MAP 

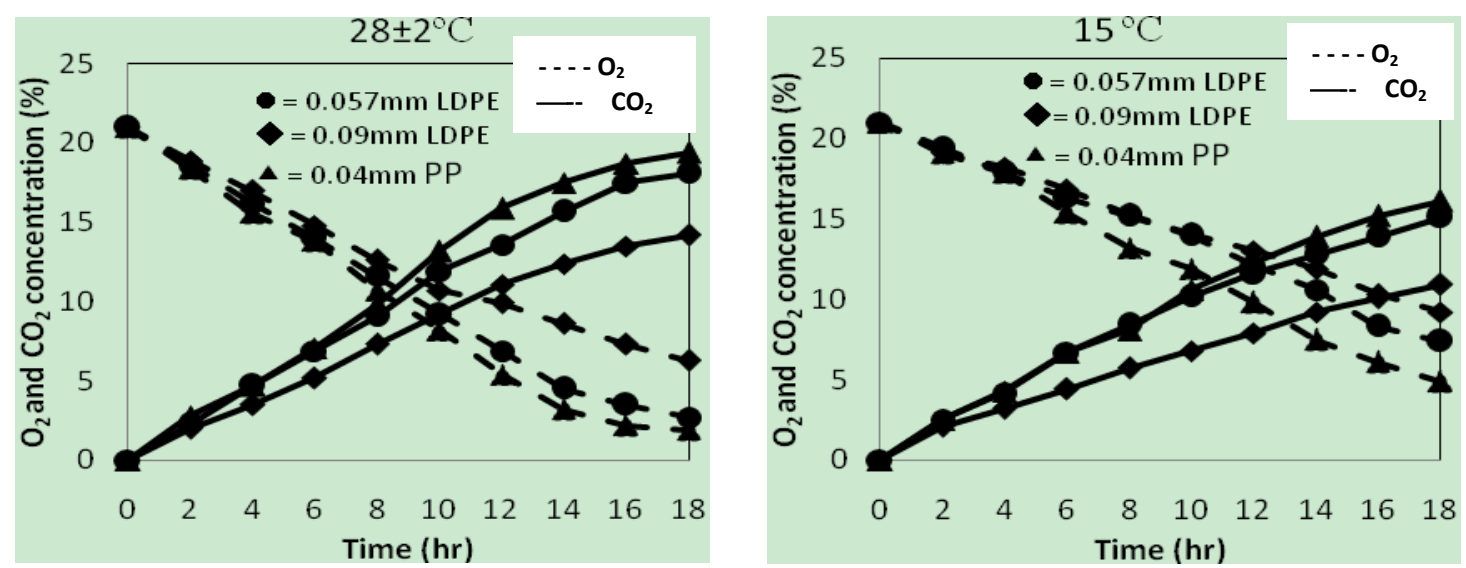

Fig. 1 Changes in $\mathrm{O}_{2}$ and $\mathrm{CO}_{2}$ concentrations in MAP-stored "barangan" banana at $28 \pm 2{ }^{\circ} \mathrm{C}$ and $15{ }^{\circ} \mathrm{C}$. Values mean 3 replicates.
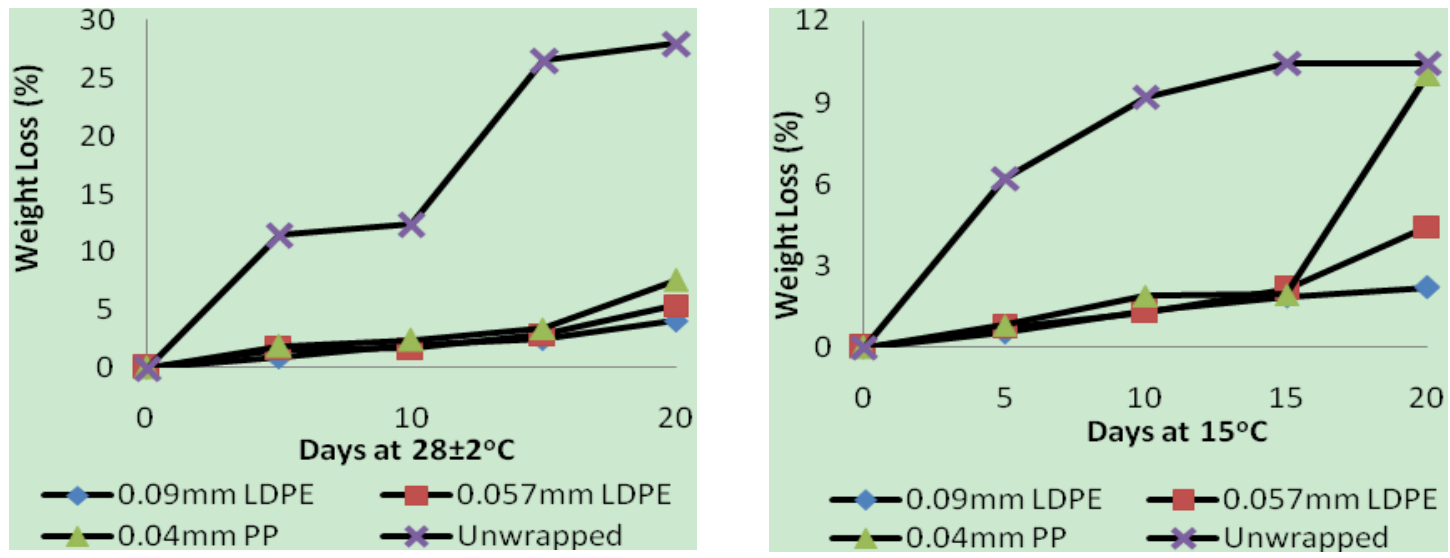

Fig. 2 Effect of modified atmosphere packages on weight loss of barangan banana during storage at $28 \pm 2{ }^{\circ} \mathrm{C}$ and $15{ }^{\circ} \mathrm{C}$.

significantly inhibited weight loss compared to control unwrapped fruits, and it was lower in $0.09 \mathrm{~mm}$ LDPE packaging compared to $0.057 \mathrm{~mm}$ LDPE and $0.04 \mathrm{~mm}$ PP and unwrapped (Table 1). On the other hand, there was a significant increase in fruit weight loss at high storage temperature $\left(28 \pm 2{ }^{\circ} \mathrm{C}\right)$ comparing with the other storage temperature $\left(15^{\circ} \mathrm{C}\right)$. Fruit stored at low temperature $\left(15{ }^{\circ} \mathrm{C}\right)$ recorded less weight loss percentage (2.21\% in $0.09 \mathrm{~mm}$ LDPE) at the end of storage period ( 20 days) than those storage at higher temperature $\left(28 \pm 2{ }^{\circ} \mathrm{C}\right)$, as shown in Fig. 2. $0.09 \mathrm{~mm}$ LDPE package provide excellent hinder against moisture loss from fruits and slow its transpiration [10].

\subsection{Changes in Sugar and Organic Acid}

Green banana had initially SSC of $1.67{ }^{\circ}$ Brix and $0.22 \%$ of total sugars in the fruit pulp (Table 1). The
SSC increased to $19.33-24.33{ }^{\circ}$ Brix and total sugars increased to $2.97 \%-18.60 \%$ on 20 days storage. The SSC and total sugars in $0.09 \mathrm{~mm}$ LDPE are lower than in $0.057 \mathrm{~mm}$ LDPE and $0.04 \mathrm{~mm}$ PP. Unwrapped barangan banana (control) had highest SSC and total sugars after 20 days of storage at ambient temperature (Fig. 3). Similar response of MAP bananas under different storage conditions was also reported [5]. The higher retention of SSC in fruits packaged in 0.09 $\mathrm{mm}$ LDPE might be due to delay in the ripening process in modified atmosphere having lower ethylenen level and decrease in respiration or other metabolic processes during storage. These results are in line with Arthey and Philip [12] and Agar and Polate [13] who had described that the higher retention of SSC is due to the slower alteration in cell wall structure and breakdown into simple sugars. 
Table 1 Changes in physical and chemical characteristics of banana (var. Barangan).

\begin{tabular}{|c|c|c|c|c|c|c|c|c|c|}
\hline & \multirow{2}{*}{$\frac{\text { Initial }}{0^{\text {th }} \text { day }}$} & \multicolumn{4}{|c|}{$20^{\text {th }}$ days at $15^{\circ} \mathrm{C}$} & \multicolumn{4}{|c|}{$20^{\text {th }}$ days at $28 \pm 2{ }^{\circ} \mathrm{C}$} \\
\hline & & $\begin{array}{l}\text { LDPE, } \\
0.09 \mathrm{~mm}\end{array}$ & $\begin{array}{l}\text { LDPE, } \\
0.057 \mathrm{~mm}\end{array}$ & $\begin{array}{ll}\mathrm{PP}, & 0.04 \\
\mathrm{~mm} & \\
\end{array}$ & Control & $\begin{array}{l}\text { LDPE, } \\
0.09 \mathrm{~mm}\end{array}$ & $\begin{array}{l}\text { LDPE, } \\
0.057 \mathrm{~mm}\end{array}$ & $\begin{array}{ll}\mathrm{PP}, & 0.04 \\
\mathrm{~mm} & \\
\end{array}$ & Control \\
\hline Weight loss (\%) & 0.00 & $2.21 \mathrm{e}$ & $4.43 \mathrm{~d}$ & $10.02 \mathrm{~b}$ & $10.45 b$ & $4.09 \mathrm{~d}$ & $5.40 \mathrm{~d}$ & $7.57 \mathrm{c}$ & $26.51 \mathrm{a}$ \\
\hline Moisture content (\%) & $75.91 \mathrm{a}$ & $70.22 \mathrm{~b}$ & $61.33 \mathrm{~d}$ & $62.01 \mathrm{~d}$ & $59.57 \mathrm{e}$ & $64.67 \mathrm{c}$ & $59.85 \mathrm{e}$ & $59.82 \mathrm{e}$ & $59.77 \mathrm{e}$ \\
\hline Vitamin C (mg/100 g) & $11.73 \mathrm{i}$ & $86.07 \mathrm{~b}$ & $64.53 f$ & $52.80 \mathrm{~h}$ & $79.20 \mathrm{~d}$ & $76.27 \mathrm{e}$ & $82.13 \mathrm{c}$ & $58.67 \mathrm{~g}$ & $114.47 \mathrm{a}$ \\
\hline TSS $\left({ }^{\circ}\right.$ Brix $)$ & $1.67 \mathrm{c}$ & $21.33 \mathrm{a}$ & $23.33 \mathrm{a}$ & $23.67 \mathrm{a}$ & $19.33 b$ & $20.67 b$ & $21.33 \mathrm{ab}$ & $23.00 \mathrm{ab}$ & $24.33 \mathrm{a}$ \\
\hline Total sugar $(\%)$ & $0.22 \mathrm{f}$ & $2.97 \mathrm{e}$ & $4.85 \mathrm{~d}$ & $3.93 \mathrm{e}$ & $5.01 \mathrm{~d}$ & $4.50 \mathrm{~d}$ & $7.50 \mathrm{c}$ & $11.43 b$ & $18.60 \mathrm{a}$ \\
\hline Firmness (g) & $8.75 \mathrm{a}$ & $2.97 \mathrm{~b}$ & $1.54 \mathrm{c}$ & $1.83 \mathrm{c}$ & $2.18 b c$ & $2.79 b$ & $2.16 \mathrm{bc}$ & $1.19 \mathrm{c}$ & $1.10 \mathrm{c}$ \\
\hline Color (Hedonic) & $2.00 \mathrm{~b}$ & $4.17 \mathrm{a}$ & $3.23 b$ & $2.77 \mathrm{~b}$ & $2.97 \mathrm{~b}$ & $4.50 \mathrm{a}$ & $2.90 \mathrm{~b}$ & $3.03 b$ & $2.80 \mathrm{~b}$ \\
\hline Texture (Hedonic) & $2.00 \mathrm{~b}$ & $4.20 \mathrm{a}$ & $3.20 \mathrm{ab}$ & $2.70 \mathrm{~b}$ & $3.03 \mathrm{ab}$ & $4.50 \mathrm{a}$ & $3.00 \mathrm{ab}$ & $2.97 \mathrm{~b}$ & $2.80 \mathrm{~b}$ \\
\hline Flavor (Hedonic) & $2.00 \mathrm{~b}$ & $4.17 \mathrm{a}$ & $3.27 \mathrm{ab}$ & $2.77 \mathrm{~b}$ & $3.00 \mathrm{ab}$ & $4.37 \mathrm{a}$ & $3.00 \mathrm{ab}$ & $2.90 \mathrm{~b}$ & $2.67 \mathrm{~b}$ \\
\hline Overall acceptance & $2.00 \mathrm{~b}$ & $4.23 \mathrm{a}$ & $3.27 \mathrm{ab}$ & $2.77 \mathrm{~b}$ & $3.00 \mathrm{ab}$ & $4.47 \mathrm{a}$ & $2.97 \mathrm{~b}$ & $2.93 b$ & $2.77 b$ \\
\hline Color (Score) & $1.00 \mathrm{~d}$ & $3.00 \mathrm{c}$ & $5.67 \mathrm{~b}$ & $4.00 \mathrm{~b}$ & $4.33 b$ & $3.67 \mathrm{c}$ & $7.33 \mathrm{a}$ & $7.00 \mathrm{a}$ & $7.67 \mathrm{a}$ \\
\hline
\end{tabular}

Values within a row followed by the same letter are not significantly different $(P \leq 0.05)$ according to Tukey's Test.

Hedonic scale for color, texture, flavor and overall aceptance: $1=$ low, $2=$ moderate, $3=$ moderate to high, $4=\operatorname{good} /$ high, $5=$ very good/very high.

Color score 1-8 according to Salunkhe and Desai [11]: $1=$ Green, $2=$ Green, trace of yellow, $3=$ More green than yellow, $4=$ more yellow than green, $5=$ yellow, green tip, $6=$ full yellow, $7=$ yellow, lightly flecked with brown, $8=$ yellow with increasing brown areas.
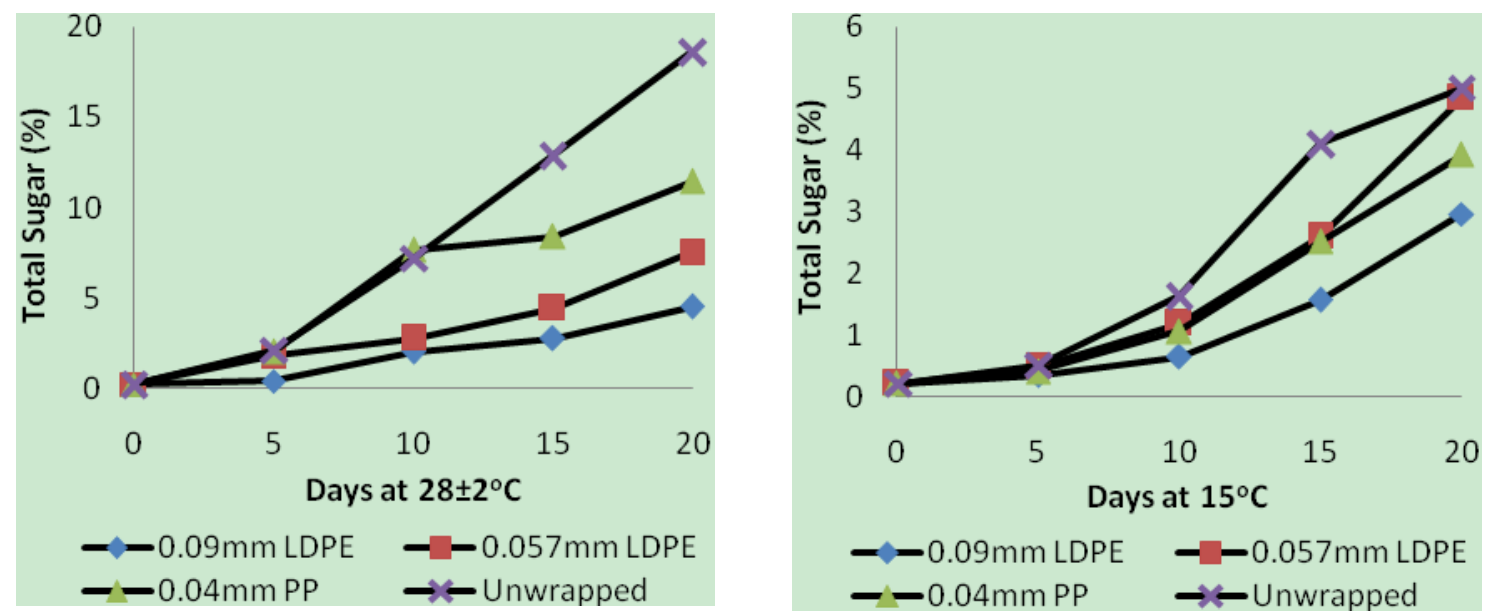

Fig. 3 Effect of modified atmosphere packages on total sugar of barangan banana during storage at $28 \pm 2{ }^{\circ} \mathrm{C}$ and $15{ }^{\circ} \mathrm{C}$.

Ascorbic acid (vitamin C) of green bananas increased after 20 days of storage. Both cold and ambient temperature storage had higher levels of ascorbic acid after 20 days of storage as compared to initial storage.

\subsection{Fruit Firmness and Color Characteristics}

Whole fruit firmness at harvest significantly decreased during cold and ambient storage, but a significant inhibition of fruit softening was found in MAP stored banana specially with $0.09 \mathrm{~mm}$ LDPE films. Changes in fruit firmness during storage in MAP banana were inversely related to weight loss of stored banana. During storage, the green bananas under MAP packages were more firm and retained the greeness in peel region during 15 days of low and ambient temperature as compared to unwrapped banana (Fig. 4). Similar observations in MAP of robusta bananas stored at low temperature were reported by Kudachikar [14] and MAP of Dwarf cavendish bananas stored under ambient storage conditions [15]. 

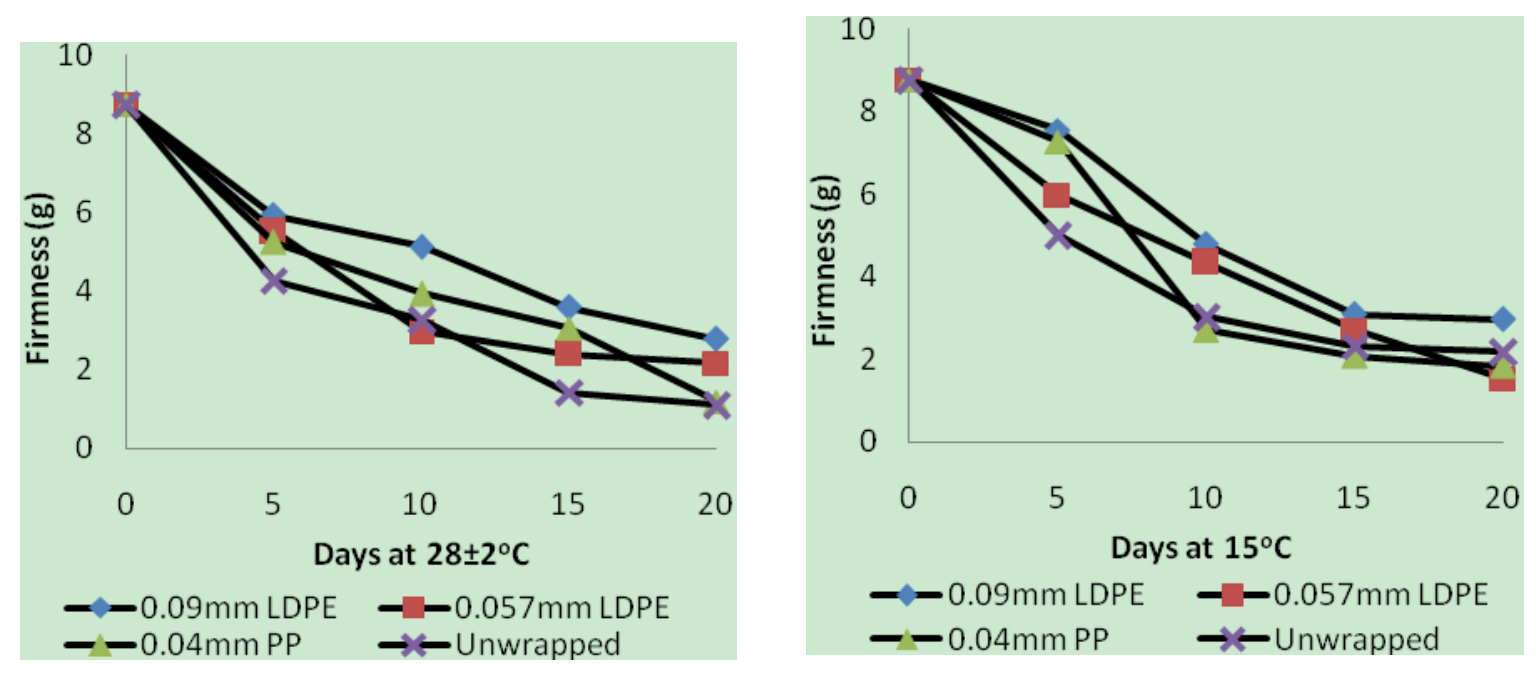

Fig. 4 Effect of modified atmosphere packages on firmness of barangan banana during storage at $28 \pm 2{ }^{\circ} \mathrm{C}$ and $15{ }^{\circ} \mathrm{C}$.

Barangan bananas packaged in $0.09 \mathrm{~mm}$ LDPE were significantly more green than in 0.057 LDPE, 0.04 PP and unwrapped bananas, as shown in color score in Tabel 1. Unwrapped bananas were more yellow than others both at ambient or $15{ }^{\circ} \mathrm{C}$ of temperature. Peel color indicates the destruction of chlorophyll [16].

\subsection{Sensory Quality}

Sensory quality (color, texture, flavor and overall acceptance) of fully ripe fruits of MAP banana after 20 days at ambient and cold storage was good and could be compared with the sensory quality of fully ripened fruits of control treatment (Table 1). Several earlier workers have stressed the importance of peel spotting during the modified atmosphere storage of banana and the restriction of the same may be attributed either to, the low levels of $\mathrm{O}_{2}$ [17] or the cytotoxic effects of excessive accumulation of $\mathrm{CO}_{2}$ [18].

\section{Conclussion}

Modified atmosphere packaging could extend the shlef life of barangan banana, and the type of plastic film used affected the gaseous atmosphere around the fruit and therefore their maximum storage life. This was shown in the delayed color changes and softening of the fruits. MAP of $6.3 \% \mathrm{O}_{2}$ and $14.2 \% \mathrm{CO}_{2}$ at $28 \pm$ $2{ }^{\circ} \mathrm{C}$ or $7.2 \% \mathrm{O}_{2}$ and $11.5 \% \mathrm{CO}_{2}$ at $15^{\circ} \mathrm{C}$ with $0.09 \mathrm{~mm}$
LDPE were effective for storage of barangan banana, keeping its overall quality and extended shelf life up to 20 days under $15^{\circ} \mathrm{C}$ and 15 days under $28 \pm 2{ }^{\circ} \mathrm{C}$.

\section{Acknowledgment}

Authors are grateful to Director General of Higher Education, Ministry of National Education Republic of Indonesia for funding this research through "Hibah Kompetensi" Project.

\section{References}

[1] Director of Horticulture Product Processing and Marketing, Ministry of Agriculture Republic of Indonesia, Banana road map: Porstharvest, process and marketing of banana product, 2005. (in Indonesian)

[2] S. Ahmad, A.K. Thompson, Effect of modified atmosphere storage on the ripening and quality of ripe banana fruit, ActaHort, (ISHS) [online], 741 (2007) 273-278, http://www.actahort.org/books/741/741_33.htm.

[3] R. Syarief, Shelf life prediction of fresh Lampung banana (Musa AAA Group) in modified atmosphere storage, J. Il. Pert. Indon. 4 (2) (1994) 47-54. (in Indonesian)

[4] S. Ketsa, C. Wongs-aree, Development of modified atmosphere packages (MAP) for sea transport of "Kulai Khai” (Banana), Acta Hort, (ISHS) [online], (1998) 464-531, http://www.actahort.org/books/464/464_119htm.

[5] V.B. Kudachikar, S.G. Kulkarni, M.N. Keshava Prakash, Effect of modified atmosphere packaging on quality and shelf life of "Robusta" banana (Musa sp.) stored at low temperature, J. Food Sci.Techol. 48 (3) (2011) 319-324.

[6] S. Ranganna, Handbook of Analysisand Quality Control 
for Fruit and Vegetable Products, 2nd ed., McGraw Hill Publishing Co. Ltd, New Delhi, 1999.

[7] D.A.T. Southgate, Determination of Food Carbohydrates, Applied Science Publ., London. 1976, p. 108.

[8] K.R. Deily, S.S.H. Rizvi, Optimization of parameter for packaging of fresh peaches in polymeric films, J.Food Sci. 109 (4) (1981) 584-587.

[9] A.A. Kader, Biochemical and physiological basis for effect of controlled and modified atmospheres on fruits and vegetables, Food Technol. 40 (5) (1985) 99.

[10] I.J. Church, A.L. Parsions, Modified atmosphere packaging technology: A review, J. Sci. Food. Agri. 67 (1995) 143-152.

[11] D.K. Salunkhe, B.B. Desai, Postharvest Biotechnology of Fruits, CRC Press Inc., Boca Raton, Florida, 1986.

[12] D. Arthey, R.A. Philip, Fruit Processing Nutrition, Product, and Quality Management, 2nd ed., Brijbasi Art Press Ltd., India, 2005, p. 45.

[13] T. Agar, A. Polate, Effect of different packingmaterials on the storage quality of some apricotvarieties, Acta Hort.
384 (1995) 625-631.

[14] V.B. Kudachikar, S.G. Kulkarni, M.S. Vasantha, B. Aravinda Prasad, S.M. Aradhya, Effect of modified atmosphere packaging on shelf life and fruit quality of banana stored at low temperature, J. Food Sci. Technol. 44 (2007) 74-78.

[15] S.V. Ramana, B.I. Mohan Kumar, K.S. Jayaraman, Effect of postharvest treatments and modified atmosphere on the storage life of fresh banana and guava under ambient temperature, Indian Food Pack 43 (1) (1989) 29-35.

[16] G.B.P. Seymour, John, A.K. Thompson, Inhibition of de-greening in the peel of bananas ripened at tropical temperature, II. Role of ethylene, oxygen and carbon dioxide, Ann. Appl. Biol. 110 (1987) 153-161.

[17] R. Choehom, S. Kesta, W.V. Doom, Senescent spotting of banana peel is inhibited by modified atmosphere packaging, Postharvest Biol. Technol. 31 (2004) 167-175.

[18] S. Satyam, K.J. Scott, D. Grahm, Storage of banana bunches in sealed polyethylene bags, J. Hortic. Sci. 67 (1992) 283-287. 